\title{
Nematicidal effect against Bursaphelenchus xylophilus of harmine quaternary ammonium derivatives, inhibitory activity and molecular docking studies on acetylcholinesterase
}

\author{
Yan Xia • Ya-meng Qi • Xi-hui Yu • Bin-feng Wang • \\ Ri-hui Cao • Ding-xin Jiang
}

Accepted: 17 July 2018 / Published online: 15 August 2018

C) Koninklijke Nederlandse Planteziektenkundige Vereniging 2018 a molecular model was provided for the binding between compound $\mathbf{1 3}$ and the active site of acetylcholinesterase based on the computational docking results and helps us to optimize these new leading compounds.

Keywords Harmine derivatives · Natural product Based nematicide $\cdot$ Acetylcholinesterase $\cdot$ Structure Activity relationships $\cdot$ Molecular docking

\section{Introduction}

The pinewood nematode, Bursaphelenchus xylophilus, is the causal agent of pine wilt disease (Kiyohara and Tokushige 1971; Mamiya 1983). The nematode is transmitted by oviposition of vector insects, such as Monochamus alternatus, in dead or dying pine trees (Kobayashi et al. 1984). Control of the disease depends primarily on fumigation of disease-infected trees, aerial application of synthetic pesticides against M. alternatus or injection of synthetic nematicides against B. xylophilus (Lee et al. 2003; Yoshida 2006). However, the discovery and development of new nematicides is getting more expensive (Chitwood 2002). For this reason, several new chemical products are in the process of being registered, and only a few commercial nematicides remain in use. Among these pesticides, organophosphates (OPs) and carbamates (CBs) pesticides are mainly used in the B. xylophilus control programme. Acetylcholinesterase (AChE), the target for the action of OPs and $\mathrm{CBs}$ pesticides that terminates nerve 
impulses by hydrolyzing the neurotransmitter acetylcholine (ACh) to acetic acid and choline at the synapses and neuromuscular junction in most vertebrates, insects and nematodes (Kang et al. 2011; Massoulie et al. 1993; Opperman and Chang 1990; Selkirk et al. 2005). Thus, the inhibition of $\mathrm{AChE}$ leads to the dysfunction of the nervous system and death (Kang et al. 2012). However, OPs and CBs pesticides are known to have negative environmental side effects, including high toxicity (Kang et al. 2013). To avoid hazards to the environment and humans caused by the use of traditional synthetic nematicides, it is necessary to find safer alternatives, that are environmentally benign, cheap and effective with a design based on naturally occurring compounds in plants.

Harmine is a beta-carboline alkaloid of Peganum harmala that possesses various types of pharmaceutical properties in vitro and in vivo (Cao et al. 2007; Lin et al. 2002), and extensive spectrum of biological activities such as antitumoral (Chen et al. 2005), antiprotozoal (Mirzaie et al. 2007), antimicrobial (Behidj-Benyounes et al. 2014; Benzekri et al. 2016), insecticidal (Chermenskaya et al. 2010; Nenaah 2011; Rharrabe et al. 2007), and nematicidal (Jakobsen et al. 2013; Ntalli and Caboni 2012) activities. A variety of mechanisms were proposed for harmine, including intercalation into DNA (Sharma et al. 2016), inhibition of cyclooxygenase (Hamsa and Kuttan 2010), monoamine oxidase (Herraiz et al. 2010), AChE (He et al. 2015; Zhang et al. 2013; Zheng et al. 2009), and interaction with L-type $\mathrm{Ca}^{2+}$ channel, opioid receptor, dopamine receptor, $\gamma$-aminobutyric acid receptor, 5-hydroxytryptamine receptor, benzodiazepine receptor, imidazoline receptor, and peroxisome proliferator-activated receptor gamma (PPAR $\gamma$ ) in the nervous system (Glennon et al. 2000; Khorana et al. 2003; Moloudizargari et al. 2013; Waki et al. 2007).

In our earlier work, we have evaluated the antitumor activity of a series of harmine derivatives by substitution of 1-, 2-, 7- and 9-position of beta-carboline nucleus through $\mathrm{C} 1$, N2, N9alkylation, and C7-oxyalkylation (Guo et al. 2014; Wu et al. 2014). However, 7-position as alkoxy group substituted harmine derivatives showed more potent neurotoxicity than harmine in our experiment (Cao et al. 2013). Here we investigate the nematicidal effect against $B$. xylophilus and inhibitory activity of these derivatives on $\mathrm{AChE}$ in vitro and in vivo.

\section{Materials and methods}

Harmine derivatives structure

Harmine derivatives were provided by Rihui Cao (Sun Yat-sen University). The structures of compounds are shown in Table 1

\section{Chemicals and instruments}

Harmine hydrochloride ( $>98 \%$ ) was obtained from AMRESCO. The following chemicals were obtained from Sigma-Aldrich (USA): dimethyl sulfoxide, AChE from electric eel (Electrophorus electricus), acetylthiocholine iodide, 5,5-dithiobisbis-nitrobenzoic acid (DTNB), L-glutathione (L-GSH), chloroform (AR), isopropanol (AR), alcohol absolute (AR).

Instruments used in the study were microplate reader (Bio-Tek Instruments, USA), Precise $\mathrm{pH}$ instrument (Lab850, SCHOTT insruments, Germany), 5804R Refrigerated centrifuge (Eppendorf, Germany), and ND1000 Nucleic acid protein quantitative instrument (Eppendorf, Germany).

\section{Nematodes}

Pinewood nematodes, B. xylophilus, were provided by the Research Center of Nematodes of Plant Quarantine of South China Agricultural University and cultured on fungal mats of Pestalotia sp. grown on potato dextrose agar (PDA) plates at $25^{\circ} \mathrm{C}$ for about ten days. Nematodes were extracted from fungal cultures with sterile distilled water in shallow pans. They were collected after $4-8 \mathrm{~h}$ and concentrated. The nematodes were rinsed from the filter disks with sterile distilled water and collected (Park et al. 2005).

Nematicidal effect

Solutions of compounds were prepared by serial dilution with distilled water containing $2 \%$ DMSO (dimethyl sulfoxide). The nematicidal effect assay was conducted, according to the method described by Kim et al. (2008) with minor modifications. Test solutions were introduced into wells of 24-well plates. In each well, the concentration of nematodes was between 150 and 200 specimens (mixtures of juveniles and adults) per $500 \mu \mathrm{l}$ of water. Controls received distilled water containing 
Table 1 Structure of harmine derivatives<smiles></smiles><smiles>COc1ccc2c(c1)[nH]c1c(C)nccc12</smiles>

Structure of harmine derivatives

Harmine

\begin{tabular}{|c|c|c|c|c|c|c|c|}
\hline Compound & $\mathrm{R}_{1}$ & $\mathrm{R}_{2}$ & $\mathrm{R}_{3}$ & $\mathrm{R}_{6}$ & $\mathrm{R}_{7}$ & $\mathrm{R}_{8}$ & $\mathrm{R}_{9}$ \\
\hline $\begin{array}{l}\text { Harmine } \\
\text { hydrochlori } \\
\text { de }\end{array}$ & $\mathrm{CH}_{3}$ & $\cdot \mathrm{Cl}^{-}$ & $\mathrm{H}$ & $\mathrm{H}$ & $\mathrm{OCH}_{3}$ & $\mathrm{H}$ & $\mathrm{H}$ \\
\hline 1 & $\mathrm{H}$ & $\begin{array}{l}\mathrm{CH}_{2} \mathrm{C}_{6} \mathrm{H}_{5} \cdot \mathrm{B} \\
\mathrm{r}^{-} \\
-\end{array}$ & $\mathrm{COOCH}_{2} \mathrm{CH}_{3}$ & $\mathrm{H}$ & $\mathrm{H}$ & $\mathrm{H}$ & $\mathrm{CH}_{2} \mathrm{C}_{6} \mathrm{H}_{5}$ \\
\hline 2 & $\mathrm{CH}_{3}$ & $\begin{array}{l}\mathrm{CH}_{2} \mathrm{C}_{6} \mathrm{H}_{5} \cdot \mathrm{B} \\
\mathrm{r}^{-}\end{array}$ & $\mathrm{H}$ & $\mathrm{H}$ & $\mathrm{H}$ & $\mathrm{H}$ & $\mathrm{CH}_{2} \mathrm{C}_{6} \mathrm{H}_{5}$ \\
\hline 3 & $\mathrm{CH}_{3}$ & - & $\mathrm{H}$ & $\mathrm{H}$ & $\mathrm{OCH}_{2} \mathrm{C}_{6} \mathrm{H}_{5}$ & $\mathrm{H}$ & $\mathrm{C}_{4} \mathrm{H}_{9}$ \\
\hline 4 & $\mathrm{CH}_{3}$ & - & $\mathrm{H}$ & $\mathrm{H}$ & $\mathrm{OC}_{6} \mathrm{H}_{13}$ & $\mathrm{H}$ & $\mathrm{C}_{4} \mathrm{H}_{9}$ \\
\hline 5 & $\mathrm{H}$ & - & $\mathrm{H}$ & $\mathrm{H}$ & $\mathrm{H}$ & $\mathrm{H}$ & $\mathrm{C}_{3} \mathrm{H}_{7}$ \\
\hline 6 & $\mathrm{CH}_{3}$ & - & $\mathrm{H}$ & $\mathrm{H}$ & $\mathrm{OCH}\left(\mathrm{CH}_{2}\right)_{2}$ & $\mathrm{H}$ & $\mathrm{C}_{4} \mathrm{H}_{9}$ \\
\hline 7 & $\mathrm{CH}_{3}$ & - & $\mathrm{H}$ & $\mathrm{H}$ & $\begin{array}{l}\mathrm{OCH}\left(\mathrm{CH}_{2} \mathrm{CH}\right. \\
\left.{ }_{3}\right)_{2}\end{array}$ & $\mathrm{H}$ & $\mathrm{C}_{4} \mathrm{H}_{9}$ \\
\hline 8 & $\mathrm{H}$ & - & $\mathrm{H}$ & $\mathrm{H}$ & $\mathrm{H}$ & $\mathrm{H}$ & $\mathrm{C}_{4} \mathrm{H}_{9}$ \\
\hline 9 & $\mathrm{CH}_{3}$ & - & $\mathrm{H}$ & $\mathrm{H}$ & $\mathrm{O}\left(\mathrm{CH}_{2}\right)_{3} \mathrm{C}_{6} \mathrm{H}_{5}$ & $\mathrm{H}$ & $\mathrm{C}_{2} \mathrm{H}_{5}$ \\
\hline 10 & $\mathrm{CH}_{3}$ & $\begin{array}{l}- \\
\mathrm{CH}_{2} \mathrm{C}_{6} \mathrm{H}_{5} . \\
\mathrm{Br}^{-}\end{array}$ & $\mathrm{H}$ & $\mathrm{H}$ & $\begin{array}{l}\mathrm{OCH}_{2} \mathrm{CH}(\mathrm{CH} \\
3)_{2}\end{array}$ & $\mathrm{H}$ & $\mathrm{C}_{4} \mathrm{H}_{9}$ \\
\hline 11 & $\mathrm{CH}_{3}$ & $-\mathrm{CH}_{2} \mathrm{C}_{6} \mathrm{H}_{5}$ & $\mathrm{H}$ & $\mathrm{H}$ & $\mathrm{O}\left(\mathrm{CH}_{2}\right)_{3} \mathrm{C}_{6} \mathrm{H}_{5}$ & $\mathrm{H}$ & $\left(\mathrm{CH}_{2}\right)_{3} \mathrm{C}_{6} \mathrm{H}_{5}$ \\
\hline 12 & $\mathrm{CH}_{3}$ & $-\mathrm{CH}_{2} \mathrm{C}_{6} \mathrm{H}_{5}$ & $\mathrm{H}$ & $\mathrm{H}$ & $\mathrm{OC}_{4} \mathrm{H}_{9}$ & $\mathrm{H}$ & $\begin{array}{l}\mathrm{CH}_{2} \mathrm{CH} \\
\left(\mathrm{CH}_{3}\right)_{2}\end{array}$ \\
\hline 13 & $\mathrm{CH}_{3}$ & $\begin{array}{l}- \\
\mathrm{CH}_{2} \mathrm{C}_{6} \mathrm{H}_{5} . \\
\mathrm{Br}^{-}\end{array}$ & $\mathrm{H}$ & $\mathrm{H}$ & $\begin{array}{l}\mathrm{OCH}_{2} \mathrm{CH}_{2} \mathrm{C}_{6} \\
\mathrm{H}_{5}\end{array}$ & $\mathrm{H}$ & $\mathrm{C}_{2} \mathrm{H}_{5}$ \\
\hline 14 & $\begin{array}{l}\mathrm{C}_{6} \mathrm{H}_{2}\left(\mathrm{OCH}_{3}\right. \\
)_{3}\end{array}$ & $\cdot \mathrm{Cl}^{-}$ & $\begin{array}{l}\mathrm{CONH}\left(\mathrm{CH}_{2}\right)_{2} \mathrm{O} \\
\mathrm{H}\end{array}$ & $\mathrm{H}$ & $\mathrm{H}$ & $\mathrm{H}$ & $\mathrm{H}$ \\
\hline 15 & $\mathrm{H}$ & $\cdot \mathrm{Cl}^{-}$ & $\begin{array}{l}\mathrm{CONH}\left(\mathrm{CH}_{2}\right)_{2} \mathrm{O} \\
\mathrm{H}\end{array}$ & $\mathrm{H}$ & $\mathrm{H}$ & $\mathrm{H}$ & $\mathrm{C}_{4} \mathrm{H}_{9}$ \\
\hline 16 & $\mathrm{H}$ & $\cdot \mathrm{Cl}^{-}$ & $\begin{array}{l}\mathrm{CONH}\left(\mathrm{CH}_{2}\right)_{2} \mathrm{O} \\
\mathrm{H}\end{array}$ & $\mathrm{H}$ & $\mathrm{H}$ & $\mathrm{H}$ & $\mathrm{CH}_{2} \mathrm{C}_{6} \mathrm{H}_{5}$ \\
\hline 17 & $\mathrm{CH}_{3}$ & - & $\mathrm{CH}_{2} \mathrm{OH}$ & $\mathrm{H}$ & $\mathrm{H}$ & $\mathrm{H}$ & $\mathrm{C}_{4} \mathrm{H}_{9}$ \\
\hline 18 & $\begin{array}{l}\mathrm{COOCH}_{2} \mathrm{C} \\
\mathrm{H}_{3}\end{array}$ & $\cdot \mathrm{Cl}^{-}$ & $\mathrm{H}$ & $\mathrm{H}$ & $\mathrm{H}$ & $\mathrm{H}$ & $\mathrm{CH}_{3}$ \\
\hline 19 & $\mathrm{H}$ & $\cdot \mathrm{Cl}^{-}$ & $\begin{array}{l}\mathrm{CONH}\left(\mathrm{CH}_{2}\right)_{2} \mathrm{O} \\
\mathrm{H}\end{array}$ & $\mathrm{H}$ & $\mathrm{H}$ & $\mathrm{H}$ & $\left(\mathrm{CH}_{2}\right)_{3} \mathrm{C}_{6} \mathrm{H}_{5}$ \\
\hline
\end{tabular}




\begin{tabular}{|c|c|c|c|c|c|c|c|}
\hline 20 & $\mathrm{H}$ & $\begin{array}{l}- \\
\mathrm{CH}_{2} \mathrm{C}_{6} \mathrm{H}_{5} . \\
\mathrm{Br}^{-}\end{array}$ & $\begin{array}{l}\mathrm{CONH}\left(\mathrm{CH}_{2}\right)_{2} \mathrm{O} \\
\mathrm{H}\end{array}$ & $\mathrm{H}$ & $\mathrm{H}$ & $\mathrm{H}$ & $\left(\mathrm{CH}_{2}\right)_{3} \mathrm{C}_{6} \mathrm{H}_{5}$ \\
\hline 21 & $\mathrm{CH}_{3}$ & - & $\mathrm{H}$ & $\mathrm{H}$ & $\mathrm{H}$ & $\mathrm{H}$ & $\mathrm{CH}_{2} \mathrm{C}_{5} \mathrm{NH}_{4}$ \\
\hline 22 & $\mathrm{CH}_{3}$ & - & $\mathrm{H}$ & $\mathrm{H}$ & $\mathrm{H}$ & $\mathrm{H}$ & $\mathrm{CH}_{2} \mathrm{C}_{5} \mathrm{NH}_{4}$ \\
\hline 23 & $\mathrm{H}$ & - & $\mathrm{H}$ & $\begin{array}{l}\mathrm{B} \\
\mathrm{r}\end{array}$ & $\mathrm{H}$ & $\mathrm{H}$ & $\mathrm{H}$ \\
\hline 24 & $\mathrm{H}$ & - & $\mathrm{H}$ & $\mathrm{H}$ & $\mathrm{H}$ & $\begin{array}{l}\mathrm{B} \\
\mathrm{r}\end{array}$ & $\mathrm{H}$ \\
\hline 25 & $\mathrm{CH}_{3}$ & $\cdot \mathrm{Cl}^{-}$ & $\mathrm{Br}$ & $\begin{array}{l}\mathrm{B} \\
\mathrm{r}\end{array}$ & $\mathrm{H}$ & $\mathrm{H}$ & $\mathrm{H}$ \\
\hline 26 & $\mathrm{H}$ & - & $\mathrm{H}$ & $\begin{array}{l}\mathrm{B} \\
\mathrm{r}\end{array}$ & $\mathrm{H}$ & $\mathrm{H}$ & $\mathrm{CH}_{3}$ \\
\hline 27 & $\mathrm{H}$ & $-\mathrm{CH}_{3} \cdot \mathrm{I}^{-}$ & $\mathrm{H}$ & $\begin{array}{l}\mathrm{B} \\
\mathrm{r}\end{array}$ & $\mathrm{H}$ & $\mathrm{H}$ & $\mathrm{CH}_{3}$ \\
\hline 28 & $\mathrm{H}$ & - & $\mathrm{H}$ & $\mathrm{H}$ & $\mathrm{H}$ & $\mathrm{H}$ & $\begin{array}{l}\mathrm{CH}_{2} \mathrm{C}_{6} \mathrm{H}_{4} \mathrm{OC} \\
\mathrm{H}_{3}\end{array}$ \\
\hline 29 & $\mathrm{H}$ & $\cdot \mathrm{Cl}^{-}$ & $\mathrm{COOCH}_{2} \mathrm{CH}_{3}$ & $\mathrm{H}$ & $\mathrm{H}$ & $\mathrm{H}$ & $\mathrm{CH}_{2} \mathrm{C}_{6} \mathrm{H}_{5}$ \\
\hline 30 & $\mathrm{H}$ & $\cdot \mathrm{Cl}^{-}$ & $\mathrm{COOCH}_{2} \mathrm{CH}_{3}$ & $\mathrm{H}$ & $\mathrm{H}$ & $\mathrm{H}$ & $\mathrm{CH}_{3}$ \\
\hline 31 & $\mathrm{H}$ & $\cdot \mathrm{Cl}^{-}$ & $\mathrm{COOC}_{4} \mathrm{H}_{9}$ & $\mathrm{H}$ & $\mathrm{H}$ & $\mathrm{H}$ & $\mathrm{H}$ \\
\hline 32 & $\mathrm{CH}\left(\mathrm{CH}_{3}\right)_{2}$ & $\cdot \mathrm{Cl}^{-}$ & $\mathrm{COOCH}_{2} \mathrm{CH}_{3}$ & $\mathrm{H}$ & $\mathrm{H}$ & $\mathrm{H}$ & $\mathrm{CH}_{2} \mathrm{CH}_{3}$ \\
\hline 33 & $\mathrm{CH}_{3}$ & $\cdot \mathrm{Cl}^{-}$ & $\mathrm{H}$ & $\mathrm{H}$ & $\mathrm{H}$ & $\mathrm{H}$ & $\mathrm{CH}_{2} \mathrm{C}_{6} \mathrm{~F}_{5}$ \\
\hline 34 & $\mathrm{CH}_{3}$ & $\cdot \mathrm{Cl}^{-}$ & $\mathrm{H}$ & $\mathrm{H}$ & $\mathrm{H}$ & $\mathrm{H}$ & $\mathrm{H}$ \\
\hline 35 & $\mathrm{CH}_{3}$ & $\begin{array}{l}\cdot \mathrm{Cl}^{-} \\
-\end{array}$ & $\mathrm{H}$ & $\mathrm{H}$ & $\mathrm{OCH}_{3}$ & $\mathrm{H}$ & $\mathrm{CH}_{2} \mathrm{C}_{6} \mathrm{H}_{5}$ \\
\hline 36 & $\mathrm{H}$ & $\begin{array}{l}\mathrm{CH}_{2} \mathrm{C}_{6} \mathrm{H}_{5} \cdot \\
\mathrm{Br}^{-}\end{array}$ & $\mathrm{H}$ & $\mathrm{H}$ & $\mathrm{H}$ & $\mathrm{H}$ & $\left(\mathrm{CH}_{2}\right)_{3} \mathrm{C}_{6} \mathrm{H}_{5}$ \\
\hline 37 & $\mathrm{H}$ & - & $\begin{array}{l}\mathrm{CH}=\mathrm{NNHC}=\mathrm{SN} \\
\mathrm{H}_{2}\end{array}$ & $\mathrm{H}$ & $\mathrm{H}$ & $\mathrm{H}$ & $\mathrm{CH}_{3}$ \\
\hline 38 & $\mathrm{H}$ & - & $\begin{array}{l}\mathrm{CH}=\mathrm{NNHC}=\mathrm{SN} \\
\mathrm{H}_{2}\end{array}$ & $\mathrm{H}$ & $\mathrm{H}$ & $\mathrm{H}$ & $\left(\mathrm{CH}_{2}\right)_{3} \mathrm{C}_{6} \mathrm{H}_{5}$ \\
\hline 39 & $\mathrm{CH}_{3}$ & - & $\begin{array}{l}\mathrm{CH}=\mathrm{NNHC}=\mathrm{SN} \\
\mathrm{H}_{2}\end{array}$ & $\mathrm{H}$ & $\mathrm{H}$ & $\mathrm{H}$ & $\mathrm{CH}_{2} \mathrm{C}_{6} \mathrm{H}_{4} \mathrm{~F}$ \\
\hline 40 & $\mathrm{H}$ & $\cdot \mathrm{Cl}^{-}$ & $\mathrm{COOCH}_{2} \mathrm{CH}_{3}$ & $\mathrm{H}$ & $\mathrm{H}$ & $\mathrm{H}$ & $\mathrm{H}$ \\
\hline 41 & $\mathrm{H}$ & $\cdot \mathrm{Cl}^{-}$ & $\mathrm{COOCH}_{2} \mathrm{CH}_{3}$ & $\mathrm{H}$ & $\mathrm{H}$ & $\mathrm{H}$ & $\mathrm{CH}_{3}$ \\
\hline 42 & $\mathrm{H}$ & $\cdot \mathrm{Cl}^{-}$ & $\mathrm{COOCH}_{2} \mathrm{CH}_{2} \mathrm{Cl}$ & $\mathrm{H}$ & $\mathrm{H}$ & $\mathrm{H}$ & $\mathrm{H}$ \\
\hline 43 & $\mathrm{H}$ & $\cdot \mathrm{Cl}^{-}$ & $\mathrm{COOCH}_{2} \mathrm{CH}_{2} \mathrm{Cl}$ & $\mathrm{H}$ & $\mathrm{H}$ & $\mathrm{H}$ & $\mathrm{CH}_{3}$ \\
\hline
\end{tabular}

2\% DMSO solution. The active compounds were diluted successively to a series of concentrations for nematicidal assay. Treated and control nematodes were kept at $25^{\circ} \mathrm{C}$. Dead and active nematodes in each well were recorded after incubation for $48 \mathrm{~h}$ under a stereomicroscope. Nematodes were defined as dead if their bodies were motionless and straightened. The mortality in the assays was corrected by eliminating natural death in the water containing $2 \%$ DMSO solution according to the formula: corrected mortality $(\%)=($ mortality of treatment- mortality of control) / (1- mortality of control $) \times 100$. Each treatment repeated three times.

Inhibitory effect on acetylcholinesterase in vitro

The inhibitory effect on AChE were measured using the spectrophotometric method, according to the method described previously (Choi et al. 2015; Ellman et al. 1961). The median inhibitory concentration $\left(\mathrm{IC}_{50}\right)$ was calculated using an enzyme inhibition dose response 
curve, with harmine hydrochloride as a positive control. The assays were conducted in triplicate.

Inhibitory effect on acetylcholinesterase in vivo

The inhibitory effect on AChE in vivo was measured using the spectrophotometric method as described previously (Revathi et al. 2013). B. xylophilus was treated by $20 \mu \mathrm{g} / \mathrm{mL}$ active compounds for $48 \mathrm{~h}$. The treated and control nematodes were washed with double distilled water and centrifuged to remove compounds. The nematodes were separately homogenized in centrifuge tubes $(1.5 \mathrm{~mL})$ using a TIANGEN hand homogenizer in $500 \mu \mathrm{L}$ of ice-cold sodium phosphate buffer $(20 \mathrm{mM}$, $\mathrm{pH}$ 7.2) to estimate the AChE enzyme activity. The homogenates were centrifuged $\left(10,000 \mathrm{~g}\right.$ at $\left.4{ }^{\circ} \mathrm{C}\right)$ for $20 \mathrm{~min}$ and supernatants were used for the further analyses. The final homogenates were held in $-20{ }^{\circ} \mathrm{C}$ until used in assays. Two hundred microlitre supernatants were mixed with $100 \mu \mathrm{L}$ sodium phosphate buffer (20 mM, pH 7.2) and $100 \mu \mathrm{L} 5 \mathrm{mM}$ substrate solution incubated for $30 \mathrm{~min}$ at $25{ }^{\circ} \mathrm{C}$. Then $100 \mu \mathrm{L} 5 \mathrm{mM}$ DTNB-ethanol reagent was added and the absorption was read immediately at $412 \mathrm{~nm}$ on a microplate reader. The median inhibitory concentration $\left(\mathrm{IC}_{50}\right)$ was calculated using an enzyme inhibition dose response curve, with harmine hydrochloride as a positive control. All experiments were performed in triplicate.

\section{Docking study}

Docking studies were performed using BioSolveIT LeadIT Version: 2.1.8 (Germany). For this purpose, crystal structure of AChE (PDB codes: 1C2O) of electric eel (Electrophorus electricus) was obtained from the Protein Data Bank in order to prepare the protein for docking studies (Bourne et al. 1999). The docking procedure was followed using the standard protocol implemented in LeadIT. The amino acid sequence of the subunit was edited to remove the extracellular region and residues. The initial structures of these compounds were built and energetically minimized. The active site of the receptor for docking studies was identified as the amino acid residues in $6.5 \AA$ pocket.

Statistical analysis

All data were expressed as means \pm standard deviations of triplicate measurements. Standard deviations (SD) did not exceed $5 \%$ for the majority of the values obtained. The treatment means were subjected to a one-way ANOVA and Tukey's multiple. The median lethal concentration $\left(\mathrm{LC}_{50}\right)$ against $B$. xylophilus and $\mathrm{IC}_{50}$ on $\mathrm{AChE}$ were obtained according to probit analysis.

\section{Results}

Nematicidal effect of harmine derivatives

Nematicidal effects of harmine hydrochloride and harmine derivatives are shown in Table 2. Compounds 10, 11, 12, 13 and 26 showed $100 \%$ nematicidal effect against B. xylophilus; compounds 20, 23, 24, 25 and 35 showed 40-90\% nematicidal effect, and slightly higher than the parent compound, harmine hydrochloride (39\%), 15 compounds had an effect ranging between 3 and $40 \%$, the other 18 compounds have no activity, at a concentration of $20 \mu \mathrm{g} / \mathrm{mL}$. In our experiment, the dead nematodes treated with harmine derivatives 10, 11, 12 and 13 usually had straight bodies, whereas nematodes treated with harmine derivatives 20, 23, 24, 25, 26 and 35 , usually had semicircular and coiling shapes.

To gain further insight into potency of these compounds, harmine hydrochloride and the compounds $\mathbf{1 0}$, $11,12,13,20,23,24,25,26$ and 35 were investigated further in a serial concentration gradient to determine their $\mathrm{LC}_{50}$ values (Table 3 ). The $\mathrm{LC}_{50}$ values of harmine hydrochloride and the compounds 10, 11, 12, 13, 20, 23, 24, 25, 26 and 35 were 27.50, 1.63, 1.63, 1.75, 1.44, $25.59,18.31,10.22,12.72,5.84$ and $13.32 \mu \mathrm{g} / \mathrm{mL}$, respectively.

Inhibitory effect of harmine derivatives against $\mathrm{AChE}$ in vitro

The inhibitory effects of harmine hydrochloride and harmine derivatives on $\mathrm{AChE}$ from electric eel in vitro were evaluated (Table 4). Compound $\mathbf{1 3}$ showed the greatest potential to inhibit AChE activity. Compounds $10,11,12$ and 13 had a prominent inhibitory effect on $\mathrm{AChE}$, with $\mathrm{IC}_{50}$ values of $0.92,0.90,0.82$ and $0.07 \mu \mathrm{g} /$ $\mathrm{mL}$, respectively. Compounds 20, 23, 24, 25 and 35 had low to moderate effect on $\mathrm{AChE}$ activity with $\mathrm{IC}_{50}$ values of $11.65,28.26,13.26,14.40$ and $5.00 \mu \mathrm{g} / \mathrm{mL}$, respectively. The $\mathrm{IC}_{50}$ values of harmine hydrochloride was $5.50 \mu \mathrm{g} / \mathrm{mL}$. However, compound $\mathbf{2 6}$ showed no inhibitory effect. 
Table 2 Preliminary nematicidal effects of harmine hydrochloride and harmine derivatives against Bursaphelenchus xylophilus at a concentration of $20 \mu \mathrm{g} / \mathrm{mL}$

\begin{tabular}{|c|c|c|c|c|c|}
\hline Compound & Mortality $\pm \mathrm{SD}(\%)$ & Compound & Mortality $\pm \mathrm{SD}(\%)$ & Compound & Mortality $\pm \mathrm{SD}(\%)$ \\
\hline Harmine hydrochloride & $39 \pm 1.5 \mathrm{e}^{*}$ & 15 & NA & 30 & NA \\
\hline 1 & $11 \pm 0.7 \mathrm{~h}$ & 16 & $5 \pm 1.0 \mathrm{k}$ & 31 & NA \\
\hline 2 & $29 \pm 1.4 \mathrm{e}$ & 17 & $9 \pm 0.9 \mathrm{i}$ & 32 & NA \\
\hline 3 & $6 \pm 0.4 \mathrm{ij}$ & 18 & $6 \pm 0.9 \mathrm{ij}$ & 33 & NA \\
\hline 4 & $\mathrm{NA}^{* *}$ & 19 & NA & 34 & NA \\
\hline 5 & $5 \pm 0.2 \mathrm{k}$ & 20 & $40 \pm 1.0 \mathrm{e}$ & 35 & $67 \pm 1.7 \mathrm{~d}$ \\
\hline 6 & $7 \pm 0.2 \mathrm{ij}$ & 21 & $3 \pm 0.5 \mathrm{~m}$ & 36 & NA \\
\hline 7 & $7 \pm 0.5 \mathrm{ij}$ & 22 & $6 \pm 0.6 \mathrm{jk}$ & 37 & NA \\
\hline 8 & $3 \pm 0.2 \mathrm{~m}$ & 23 & $66 \pm 2.2 \mathrm{~d}$ & 38 & NA \\
\hline 9 & $19 \pm 0.1 \mathrm{f}$ & 24 & $87 \pm 1.2 \mathrm{~b}$ & 39 & NA \\
\hline 10 & $100 \pm 0.0 \mathrm{a}$ & 25 & $76 \pm 1.5 \mathrm{c}$ & 40 & NA \\
\hline 11 & $100 \pm 0.0 \mathrm{a}$ & 26 & $100 \pm 0.0 \mathrm{a}$ & 41 & NA \\
\hline 12 & $100 \pm 0.0 \mathrm{a}$ & 27 & $16 \pm 0.9 \mathrm{~g}$ & 42 & NA \\
\hline 13 & $100 \pm 0.0 \mathrm{a}$ & 28 & NA & 43 & NA \\
\hline 14 & NA & 29 & $4 \pm 0.71$ & & \\
\hline
\end{tabular}

*Means followed by the same letters are not significantly different based on one-way ANOVA at $P=0.05$ (Tukey's test); **NA, not active

Inhibitory effect of harmine derivatives against $\mathrm{AChE}$ in vivo

Because these compounds showed good inhibitory effect on AChE in vitro, we further evaluated the inhibitory effect of harmine hydrochloride and harmine derivatives on AChE of B. xylophilus in vivo. Similar results were obtained (Table 5). Compound $\mathbf{1 3}$ proved to be the most active. $\mathrm{IC}_{50}$ values of the compounds 10, 11, 12 and $\mathbf{1 3}$ were $17.16,14.56,13.63$ and $3.06 \mu \mathrm{g} / \mathrm{mL}$, respectively, significantly lower than that of harmine hydrochloride, $578.44 \mu \mathrm{g} / \mathrm{mL}$. Compound 20, 23, 24, 25, 26 and 35 had no effect.

Study on structure-activity relationship (SAR)

In our study, 2,7,9-trisubstituted harmine derivative 10, 11, 12, 13, 20, 23, 24, 25, 26 and 35 showed good nematicidal effect (Table 1). Among the 2,9-positions together as the electron-donating substituted and the 7

Table 3 Nematicidal effects of harmine hydrochloride and harmine derivatives against Bursaphelenchus xylophilus

\begin{tabular}{lllll}
\hline Compound & $\mathrm{LC}_{50}(\mu \mathrm{g} / \mathrm{mL})$ & Linear equation & Confidence interval $(\mu \mathrm{g} / \mathrm{mL})$ & $\mathrm{R}$ \\
\hline Harmine hydrochloride & 27.50 & $\mathrm{Y}=2.8947+1.4628 \mathrm{X}$ & $21.37-35.38$ & 0.9796 \\
$\mathbf{1 0}$ & 1.63 & $\mathrm{Y}=4.3611+3.0060 \mathrm{X}$ & $1.45-1.83$ & 0.9993 \\
$\mathbf{1 1}$ & 1.63 & $\mathrm{Y}=4.2081+3.7193 \mathrm{X}$ & $1.44-1.85$ & 0.9308 \\
$\mathbf{1 2}$ & 1.75 & $\mathrm{Y}=4.2978+2.8946 \mathrm{X}$ & $1.55-1.98$ & 0.9938 \\
$\mathbf{1 3}$ & 1.44 & $\mathrm{Y}=4.5374+2.9248 \mathrm{X}$ & $1.28-1.62$ & 0.9616 \\
$\mathbf{2 0}$ & 25.59 & $\mathrm{Y}=2.1589+2.0177 \mathrm{X}$ & $21.01-31.18$ & 0.9162 \\
$\mathbf{2 3}$ & 18.31 & $\mathrm{Y}=1.9513+2.4145 \mathrm{X}$ & $15.84-21.16$ & 0.9198 \\
$\mathbf{2 4}$ & 10.22 & $\mathrm{Y}=2.3001+2.6749 \mathrm{X}$ & $9.11-11.46$ & 0.9283 \\
$\mathbf{2 5}$ & 12.72 & $\mathrm{Y}=2.2752+2.4667 \mathrm{X}$ & $11.24-14.40$ & 0.9911 \\
$\mathbf{2 6}$ & 5.84 & $\mathrm{Y}=2.5876+3.1481 \mathrm{X}$ & $5.24-6.50$ & 0.9996 \\
$\mathbf{3 5}$ & 13.32 & $\mathrm{Y}=1.5363+3.0805 \mathrm{X}$ & $11.94-14.86$ & 0.9933 \\
\hline
\end{tabular}


Table 4 Inhibition of acetylcholinesterase by harmine hydrochloride and harmine derivatives in vitro

\begin{tabular}{|c|c|c|c|c|}
\hline Compound & $\mathrm{IC}_{50}(\mu \mathrm{g} / \mathrm{mL})$ & Linear equation & $95 \%$ Confidence interval $(\mu \mathrm{g} / \mathrm{mL})$ & $\mathrm{R}$ \\
\hline Harmine hydrochloride & 5.50 & $Y=4.0704+1.2558 X$ & $4.33-6.98$ & 0.9970 \\
\hline 10 & 0.92 & $Y=5.0627+1.7379 X$ & $0.76-1.12$ & 0.9880 \\
\hline 11 & 0.90 & $\mathrm{Y}=5.0906+1.9143 \mathrm{X}$ & $0.77-1.04$ & 0.9756 \\
\hline 12 & 0.82 & $\mathrm{Y}=5.1087+1.2952 \mathrm{X}$ & $0.67-1.01$ & 0.9969 \\
\hline 13 & 0.07 & $Y=7.1565+1.8382 X$ & $0.05-0.08$ & 0.9778 \\
\hline 20 & 11.65 & $Y=3.4692+1.4726 X$ & $9.15-14.84$ & 0.9878 \\
\hline 23 & 28.26 & $\mathrm{Y}=3.6456+0.9334 \mathrm{X}$ & $15.76-50.66$ & 0.9531 \\
\hline 24 & 13.26 & $\mathrm{Y}=2.9817+1.7978 \mathrm{X}$ & $10.40-16.90$ & 0.9965 \\
\hline 25 & 14.40 & $Y=4.0892+0.7862 X$ & $9.01-23.02$ & 0.9218 \\
\hline 26 & $>50$ & - & - & - \\
\hline 35 & 5.00 & $\mathrm{Y}=3.5868+2.0224 \mathrm{X}$ & $4.33-5.76$ & 0.9823 \\
\hline
\end{tabular}

"-_" Absent

position as electron-withdrawing substituted harmine derivatives 10, 11, 12 and 13, showed $100 \%$ mortality at a concentration of $20 \mu \mathrm{g} / \mathrm{mL}$, with $\mathrm{LC}_{50}$ values of $1.63,1.63,1.75$ and $1.44 \mu \mathrm{g} / \mathrm{mL}$, respectively (Tables 2 and 3), and had also a remarkable inhibitory effect on AChE activity, with $\mathrm{IC}_{50}$ values of $0.92,0.90,0.82$ and $0.07 \mu \mathrm{g} / \mathrm{mL}$ in vitro and 17.16, 14.56, 13.63 and $3.06 \mu \mathrm{g} / \mathrm{mL}$ in vivo, respectively (Tables 4 and 5 ). In the case of compound $\mathbf{2 0}$ with 2,9-positions together as the electron-donating substituent groups, compounds 23 and 25 with 6-position as bromine, compound 24 with 8 -position as bromine and compound 35 with 7-position as electron-withdrawing substituent groups, showed 40-87\% mortality at a concentration of $20 \mu \mathrm{g} / \mathrm{mL}$, with $\mathrm{LC}_{50}$ values of $25.59,18.31,12.72,10.22$ and $13.32 \mu \mathrm{g} / \mathrm{mL}$, respectively (Tables 2 and 3 ). These compounds had a moderate inhibitory effect on AChE activity in vitro, with $\mathrm{IC}_{50}$ values of $11.65,28.26,14.40$, 13.26 and $5.00 \mu \mathrm{g} / \mathrm{mL}$, respectively (Table 4), but had no inhibitory effect in vivo (Table 5). In addition, the harmine derivative 26, with 9-position as the electron-donating and 6-position as bromine substituted, showed also $100 \%$ mortality at a concentration of $20 \mu \mathrm{g} / \mathrm{mL}$, with $\mathrm{LC}_{50}$ values of $5.84 \mu \mathrm{g} / \mathrm{mL}$ (Tables 2 and 3); but showed no inhibitory effect on $\mathrm{AChE}$ activity in vitro nor in vivo in our experiment (Table 5).

Table 5 Inhibition of acetylcholinesterase by harmine hydrochloride and harmine derivatives in vivo

\begin{tabular}{|c|c|c|c|c|}
\hline Compound & $\mathrm{IC}_{50}(\mu \mathrm{g} / \mathrm{mL})$ & Linear equation & Confidence interval $(\mu \mathrm{g} / \mathrm{mL})$ & $\mathrm{R}$ \\
\hline Harmine hydrochloride & 578.44 & $Y=3.8723+0.4083 X$ & $61.57-11,693.53$ & 0.9123 \\
\hline 10 & 17.16 & $\mathrm{Y}=4.0378+0.7794 \mathrm{X}$ & $9.88-29.81$ & 0.9842 \\
\hline 11 & 14.56 & $Y=4.0952+0.7778 X$ & $6.99-30.33$ & 0.9955 \\
\hline 12 & 13.63 & $\mathrm{Y}=3.9227+0.9495 \mathrm{X}$ & $7.47-24.86$ & 0.9939 \\
\hline 13 & 3.06 & $Y=4.6811+0.6568 X$ & $2.05-4.56$ & 0.9269 \\
\hline 20 & $>600$ & - & - & - \\
\hline 23 & $>600$ & - & - & - \\
\hline 24 & $>600$ & - & - & - \\
\hline 25 & $>600$ & - & - & - \\
\hline 26 & $>600$ & - & - & - \\
\hline 35 & $>600$ & - & - & - \\
\hline
\end{tabular}

"-_" Absent 
Docking study

To clarify the binding mode of our synthesized compounds, compound $\mathbf{1 3}$ with high AChE inhibitory activity was docked into the active site of AChE by FlexX $X^{\text {TM }}$ Docking within BioSolveIT LeadIT Version: 2.1.8 software package. The result revealed that compound $\mathbf{1 3}$ was flexibly docked automatically in the active site of AChE. Firstly, the beta-carboline ring and the ethyl group in 9- position of harmine derivatives are oriented into substrate access AChE in the middle and forms hydrophobic and Van der Waals interactions with surrounding hydrophobic residues (yellow). Secondly, the phenyl group attached to the beta-carboline of the side chain interacts with the phenyl group of aromatic amino acids through the formation of $\pi-\pi$ face-to-edge interaction and $\mathrm{N}^{+}$cation in 2-position interacts with the anionic site in the peripheral anionic site (PAS) (green). Furthermore, the phenethoxy group in 7- position of beta-carboline can bind to the catalytic active site (CAS) (orange) of $\mathrm{AChE}$ through the former binding mode (Fig. 1).

\section{Discussion}

The naturally and synthetic beta-carboline derivatives provide a valuable scaffold in medicinal chemistry as well as agrochemical applications with herbicidal, fungicidal, insecticidal and nematicidal activities (Bloomquist et al. 1997; El Hassan et al. 2013; Larson et al. 1988; Li et al. 2015; Liu et al. 2014; Saeed and Shawkat 2014; Sodaeizadeh et al. 2010; Song et al. 2014). In the current study, we report the 2,7,9-trisubstituted harmine derivatives against $B$. xylophilus and their inhibitory effects on AChE in vitro and in vivo and detailed studies of SAR. This work clearly shows that compounds 10, 11, 12 and 13 with 2,9-positions together as electron-donating substituent groups and the 7-position as electron-withdrawing substituent group caused $100 \%$ mortality at a concentration of $20 \mu \mathrm{g} / \mathrm{mL}$ and had remarkable inhibitory effect on AChE activity in vitro and in vivo. This result agrees with previous findings that the substituent at the 7-position of the beta-carboline alkaloids and 3,9-positions of quinoline alkaloids played a critical role in AChE or BChE inhibition (Yang et al. 2015; Zhao et al. 2013;

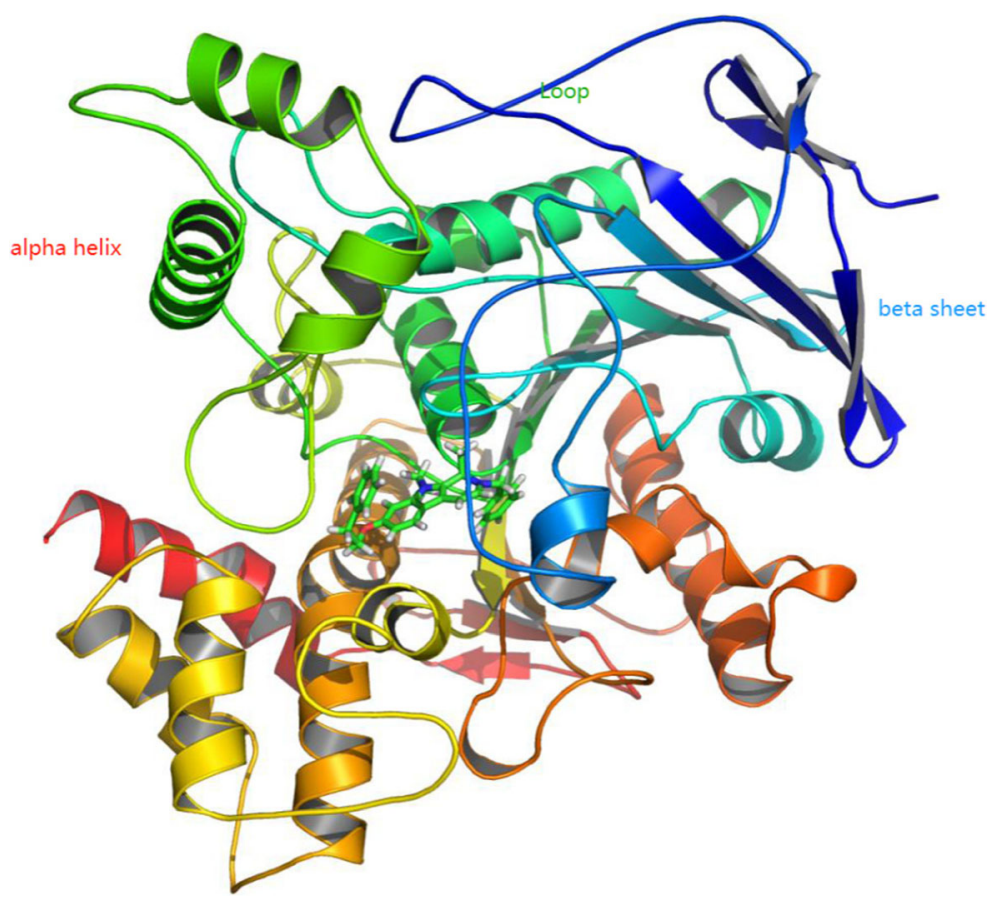

Fig. 1 Simulated binding site interactions of compound 13 with the acetylcholinesterase (AChE) structure of electric eel (Electrophorus electricus) depicted as spectrum-colored cartoon (containing $\alpha$-helix, $\beta$-sheet and flexible loop) and the arrow shows the AChE core (yellow) colored in spectrum with the $\mathrm{N}$-terminus beginning in blue and the $\mathrm{C}$ terminus finishing in red. The carbon atoms of compound $\mathbf{1 3}$ are green. Simulated docking shows docking compound $\mathbf{1 3}$ in the same site formed $\pi-\pi$ stacking interactions and hydrogen bonding 
Zheng et al. 2009). This also agrees with previous findings that 2,9-positions together as the electron-donating substituted and 7-position as electron-withdrawing substituted harmine derivatives had remarkable neurotoxic effects including tremor, twitch and jumping in experimental animal models and cytotoxic properties in vitro (Shi et al. 2013). Due to the different residues in the PAS, the three AChEs (BxACE-1, BxACE-2, BxACE-3) of pinewood nematode showed differential inhibition properties by the plant essential oils, organophosphates (OPs) and carbamates (CBs) (Kang et al. 2011, 2012, 2013). The differential inhibition activities against $\mathrm{AChE}$ in vitro and in vivo of harmine derivatives can be helpful in developing an efficient anti-AChE nematicidal agent for control of pinewood nematode.

On the other hand, compound $\mathbf{2 6}$ with 9-position as electron-donating substituent groups and 6-position as bromine, compound $\mathbf{2 0}$ with 2,9-positions together as the electron-donating substituent groups, compounds 23 and 25 with 6-position as bromine, compound 24 with 8-position as bromine and compound 35 with 7position as electron-withdrawing substituent groups caused $40-100 \%$ mortality at a concentration of $20 \mu \mathrm{g} / \mathrm{mL}$, but proved to be ineffective in inhibiting $\mathrm{AChE}$ in vitro and in vivo, and so their exact mode of action against pinewood nematode is unclear. Kong et al. (2006) reported that pinewood nematode bodies treated with the muscle activity blockers levamisole hydrochloride and morantal tatrate usually exhibited semicircular and coiling shapes, respectively. Because the symptoms resemble nerve intoxication, we speculate that the compounds might act on the nervous system.

These results suggest that the nematicidal mode of action among the different substituent groups of harmine derivatives might be different. As compared with previous work, the binding conformation of compound $\mathbf{1 3}$ in this docking simulation showed the similar binding mode of alkylene-linked tacrine dimers (Chen et al. 2014; Lu et al. 2011; Rydberg et al. 2006). It helps us to optimize these harmine derivatives to inhibit AChE. To some extent, these findings, combined with the SARs results, could explain the novel mechanism of the nematicidal effect by these new derivatives.

Overall, harmine derivatives 10, 11, 12 and 13, appear to be useful as natural product-based nematicides for B. xylophilus through inhibition of AChE. In addition, the docking results revealed that the structural uniqueness of our newly designed harmine derivatives led to a unique molecular recognition and binding mode and were in good agreement with their high nematicidal potential, which also explained the SARs observed in vitro and in vivo. These results suggest that betacarboline nucleus is the primary pharmacophore of the nematicidal activity of beta-carboline derivatives and may be helpful in structure-guided design and development of novel nematicidal harmine derivatives based on AChE inhibitors. Since harmine derivatives 20, 23, 24, 25, 26 and 35, have potential as natural product-based nematicides for B. xylophilus, the mechanism of their nematicidal activity deserves further study. The active derivatives could be considered as potential alternatives to currently used pinewood nematode control agents or as lead compounds for the development of synthetic environment friendly nematicides with enhanced activity.

Acknowledgements The work was supported by the Science and Technology Planning Project of Guangdong Province, China [grant numbers 2016A020210082]; the Science and Technology Program of Guangzhou, China [grant numbers 201607010181]; the Science and Technology Program of Zhongshan, China [grant numbers 2016F2FC0016]; the National Natural Science Foundation of China [grant numbers 31171871]. We are grateful to $\mathrm{Xu}$ Zenglin (College of Food Science, South China Agricultural University) for expert assistance in molecule docking study.

\section{Compliance with ethical standards}

Conflict of interest All authors certify that 1) they do not have any actual or potential conflict of interest, 2) the study described is original and has not been published previously, and is not under consideration for publication elsewhere, 3) all prevailing local, national and international regulations and conventions, and normal scientific ethical practices, have been respected. We also certify that all authors have reviewed the manuscript and approved the final version of manuscript before submission.

Human and animal subjects This article does not contain any studies with human or animal subjects.

Informed consent All the authors certify that the work carried out in this research followed the principles of ethical and professional conduct have been followed. The funders had no role in study design, data collection and analysis, decision to publish, or preparation of the manuscript.

\section{References}

Behidj-Benyounes, N., Dahmene, T., Allouche, N., \& Laddad, A. (2014). Phytochemical, antibacterial and antifungal activities of alkaloids extracted from Peganum harmala (Linn.) seeds of south of Algeria. Asian Journal of Chemistry, 26(10B), 2960-2964. 
Benzekri, R., Bouslama, L., Papetti, A., Snoussi, M., Benslimene, I., Hamami, M., \& Limam, F. (2016). Isolation and identification of an antibacterial compound from Diplotaxis harra (Forssk.) Boiss. Industrial Crops and Products, 80, 228-234.

Bloomquist, J. R., Ferguson, H. J., Cox, E. D., Reddy, M. S., \& Cook, J. M. (1997). Mode of action of beta-carboline convulsants on the insect nervous system and their potential as insecticides. Pesticide Science, 51(1), 1-6.

Bourne, Y., Grassi, J., Bougis, P. E., \& Marchot, P. (1999). Conformational flexibility of the acetylcholinesterase tetramer suggested by X-ray crystallography. Journal of Biological Chemistry, 274(43), 30370-30376.

Cao, R., Peng, W., Wang, Z., \& Xu, A. (2007). Beta-Carboline alkaloids: Biochemical and pharmacological functions. Current Medicinal Chemistry, 14(4), 479-500.

Cao, R., Fan, W., Guo, L., Ma, Q., Zhang, G., Li, J., Chen, X., Ren, Z., \& Qiu, L. (2013). Synthesis and structure-activity relationships of harmine derivatives as potential antitumor agents. European Journal of Medicinal Chemistry, 60, 135-143.

Chen, Q., Chao, R. H., Chen, H. S., Hou, X. R., Yan, H. F., Zhou, S. F., Peng, W. L., \& Xu, A. L. (2005). Antitumor and neurotoxic effects of novel harmine derivatives and structure-activity relationship analysis. International Journal of Cancer, 114(5), 675-682.

Chen, X., Wehle, S., Kuzmanovic, N., Merget, B., Holzgrabe, U., Koenig, B., Sotriffer, C. A., \& Decker, M. (2014). Acetylcholinesterase inhibitors with Photoswitchable inhibition of beta-amyloid aggregation. ACS Chemical Neuroscience, 5(5), 377-389.

Chermenskaya, T. D., Stepanycheva, E. A., Shchenikova, A. V., \& Chakaeva, A. S. (2010). Insectoacaricidal and deterrent activities of extracts of Kyrgyzstan plants against three agricultural pests. Industrial Crops and Products, 32(2), 157-163.

Chitwood, D. J. (2002). Phytochemical based strategies for nematode control. Annual Review of Phytopathology, 40(1), 221-249.

Choi, J. S., Haulader, S., Karki, S., Jung, H. J., Kim, H. R., \& Jung, H. A. (2015). Acetyl- and butyryl-cholinesterase inhibitory activities of the edible brown alga Eisenia bicyclis. Archives of Pharmacal Research, 38(8), 1477-1487.

El Hassan, M., Zahra, F., \& Mina, I. H. L. (2013). Anti-nematode effect assessment of Peganum harmala based-products against Meloidogyne javanica on melon. Journal of Biology, Agriculture and Healthcare, 3, 5-10.

Ellman, G. L., Courtney, K. D., Andres, V. J., \& Feather-Stone, R. M. (1961). A new and rapid colorimetric determination of acetylcholinesterase activity. Biochemical Pharmacology, 7, 88-95.

Glennon, R. A., Dukat, M., Grella, B., Hong, S., Costantino, L., Teitler, M., Smith, C., Egan, C., Davis, K., \& Mattson, M. V. (2000). Binding of beta-carbolines and related agents at serotonin (5-HT2 and 5-HT1A), dopamine (D2) and benzodiazepine receptors. Drug and Alcohol Dependence, 60(2), 121-132.

Guo, L., Cao, R., Fan, W., \& Ma, Q. (2014). Synthesis and biological evaluation of 1,2,7,9-Tetrasubstituted Harmine derivatives as potential antitumor agents. Chemical Journal of Chinese Universities-Chinese, 35(3), 518-523.

Hamsa, T. P., \& Kuttan, G. (2010). Harmine inhibits tumour specific neo-vessel formation by regulating VEGF,
MMP, TIMP and pro-inflammatory mediators both in vivo and in vitro. European Journal of Pharmacology, 649(1-3), 64-73.

He, D., Wu, H., Wei, Y., Liu, W., Huang, F., Shi, H., Zhang, B., Wu, X., \& Wang, C. (2015). Effects of harmine, an acetylcholinesterase inhibitor, on spatial learning and memory of APP/PS1 transgenic mice and scopolamine-induced memory impairment mice. European Journal of Pharmacology, 768, 96-107.

Herraiz, T., Gonzalez, D., Ancin-Azpilicueta, C., Aran, V. J., \& Guillen, H. (2010). Beta-Carboline alkaloids in Peganum harmala and inhibition of human monoamine oxidase (MAO). Food and Chemical Toxicology, 48(3), 839-845.

Jakobsen, H., Bojer, M. S., Marinus, M. G., Xu, T., Struve, C., Krogfelt, K. A., \& Lobner-Olesen, A. (2013). The alkaloid compound Harmane increases the lifespan of Caenorhabditis elegans during bacterial infection, by modulating the Nematode's innate immune response. PLoS One, 8(e605193), e60519.

Kang, J. S., Lee, D. W., Choi, J. Y., Je, Y. H., Koh, Y. H., \& Lee, S. H. (2011). Three acetylcholinesterases of the pinewood nematode, Bursaphelenchus xylophilus: Insights into distinct physiological functions. Molecular and Biochemical Parasitology, 175(2), 154-161.

Kang, J. S., Moon, Y. S. \& Lee, S. H. (2012). Inhibition properties of three acetylcholinesterases of the pinewood nematode Bursaphelenchus xylophilus by organophosphates and carbamates. Pesticide Biochemistry and Physiology, 104(2SI), 157-162.

Kang, J. S., Kim, E., Lee, S. H., \& Park, I. (2013). Inhibition of acetylcholinesterases of the pinewood nematode, Bursaphelenchus xylophilus, by phytochemicals from plant essential oils. Pesticide Biochemistry and Physiology, 105(1), $50-56$.

Khorana, N., Smith, C., Herrick-Davis, K., Purohit, A., Teitler, M., Grella, B., Dukat, M., \& Glennon, R. A. (2003). Binding of tetrahydrocarboline derivatives at human 5-HT5A receptors. Journal of Medicinal Chemistry, 46(18), 3930-3937.

Kim, J., Seo, S., Lee, S., Shin, S., \& Park, I. (2008). Nematicidal activity of plant essential oils and components from coriander (Coriandrum sativum), oriental sweetgum (Liquidambar orientalis), and valerian (Valeriana wallichii) essential oils against pine wood nematode (Bursaphelenchus xylophilus). Journal of Agricultural and Food Chemistry, 56(16), 7316-7320.

Kiyohara, T., \& Tokushige, Y. (1971). Inoculation experiments of a nematode, Bursaphelenchus sp., onto pine trees. Journal of the Japanese Forestry Society, 53(7), 210-218.

Kobayashi, F., Yamane, A., \& Ikeda, T. (1984). The Japanese pine sawyer beetle as the vector of pine wilt disease. Annual Review of Entomology, 29(1), 115-135.

Kong, J., Lee, S., Moon, Y., Lee, S., \& Ahn, Y. (2006). Nematicidal activity of plant essential oils against Bursaphelenchus xylophilus (Nematoda: Aphelenchoididae). Journal of AsiaPacific Entomology, 9(2), 173-178.

Larson, R. A., Marley, K. A., Tuveson, R. W., \& Berenbaum, M. R. (1988). Beta-carboline alkaloids: Mechanisms of phototoxicity to bacteria and insects. Photochemistry and Photobiology, 48(5), 665-674.

Lee, S. M., Chung, Y. J., Moon, Y. S., Lee, S. G., Lee, D. W., Choo, H. Y., \& Lee, C. K. (2003). Insecticidal activity and 
fumigation conditions of several insecticides against Japanese pine sawyer (Monochamus alternatus) larvae. Journal of Korean Forestry Society, 92(3), 191-198.

Li, Z., Chen, S., Zhu, S., Luo, J., Zhang, Y., \& Weng, Q. (2015). Synthesis and fungicidal activity of beta-Carboline alkaloids and their derivatives. Molecules, 20(8), 13941-13957.

Lin, N., Zhao, M., Wang, C., \& Peng, S. (2002). Synthesis and antithrombotic activity of carbolinecarboxyl RGD sequence. Bioorganic \& Medicinal Chemistry Letters, 12(4), 585-587.

Liu, Y., Song, H., Huang, Y., Li, J., Zhao, S., Song, Y., Yang, P., Xiao, Z., Liu, Y., Li, Y., Shang, H., \& Wang, Q. (2014). Design, synthesis, and antiviral, fungicidal, and insecticidal activities of Tetrahydro-beta-carboline-3-carbohydrazide derivatives. Journal of Agricultural and Food Chemistry, 62(41), 9987-9999.

Lu, S., Wu, J. W., Liu, H., Zhao, J., Liu, K., Chuang, C., Lin, H., Tsai, W., \& Ho, Y. (2011). The discovery of potential acetylcholinesterase inhibitors: A combination of pharmacophore modeling, virtual screening, and molecular docking studies. Journal of Biomedical Science, 18, 8.

Mamiya, Y. (1983). Pathology of the pine wilt disease caused by Bursaphelenchus xylophilus. Annual Review of Phytopathology, 21, 201-220.

Massoulie, J., Pezzementi, L., Bon, S., Krejci, E., \& Vallette, F. M. (1993). Molecular and cellular biology of cholinesterases. Progress in Neurobiology, 41(1), 31-91.

Mirzaie, M., Nosratabadi, S. J., Derakhshanfar, A., \& Sharifi, I. (2007). Antileishmanial activity of Peganum harmala extract on the in vitro growth of Leishmania major promastigotes in comparison to a trivalent antimony drug. Veterinarski Arhiv, 77(4), 365-375.

Moloudizargari, M., Mikaili, P., Aghajanshakeri, S., Asghari, M. H., \& Shayegh, J. (2013). Pharmacological and therapeutic effects of Peganum harmala and its main alkaloids. Pharmacognosy Reviews, 7(14), 199-212.

Nenaah, G. (2011). Toxicity and growth inhibitory activities of methanol extract and the beta-carboline alkaloids of Peganum harmala L. against two coleopteran stored-grain pests. Journal of Stored Products Research, 47(3), 255-261.

Ntalli, N. G., \& Caboni, P. (2012). Botanical Nematicides: A review. Journal of Agricultural and Food Chemistry, 60(40), 9929-9940.

Opperman, C. H., \& Chang, S. (1990). Plant-parasitic nematode acetylcholinesterase inhibition by carbamate and organophosphate Nematicides. Journal of Nematology, 22(4), 481-488.

Park, I. K., Park, J. Y., Kim, K. H., Choi, K. S., Choi, I. H., Kim, C. S., \& Shin, S. C. (2005). Nematicidal activity of plant essential oils and components from garlic (Allium sativum) and cinnamon (Cinnamomum verum) oils against the pine wood nematode (Bursaphelenchus xylophilus). Nematology, 7(5), 767-774.

Revathi, K., Chandrasekaran, R., Thanigaivel, A., Kirubakaran, S. A., Sathish-Narayanan, S., \& Senthil-Nathan, S. (2013). Effects of Bacillus subtilis metabolites on larval Aedes aegypti L. Pesticide Biochemistry and Physiology, 107(3), 369-376.

Rharrabe, K., Bakrim, A., Ghailani, N., \& Sayah, F. (2007). Bioinsecticidal effect of harmaline on Plodia interpunctella development (Lepidoptera: Pyralidae). Pesticide Biochemistry and Physiology, 89(2), 137-145.
Rydberg, E. H., Brumshtein, B., Greenblatt, H. M., Wong, D. M., Shaya, D., Williams, L. D., Carlier, P. R., Pang, Y. P., Silman, I., \& Sussman, J. L. (2006). Complexes of Alkylene-linked Tacrine dimers with Torpedo c alifornica acetylcholinesterase: Binding of Bis (5)-tacrine produces a dramatic rearrangement in the active-site gorge. Journal of Medicinal Chemistry, 49(18), 5491-5500.

Saeed, M., \& Shawkat, J. N. (2014). Nematicidal effect of some botanical powders and poultry manure against the root-knot nematode Meloidogyne incognita (Kofoid and white) Chitwood infecting tomato plants. Egyptian Journal of Agronematology, 13(1), 160-171.

Selkirk, M. E., Lazari, O., \& Matthews, J. B. (2005). Functional genomics of nematode acetylcholinesterases. Parasitology, $131 S$, S3-S18.

Sharma, S., Yadav, M., Gupta, S. P., Pandav, K., \& Kumar, S. (2016). Spectroscopic and structural studies on the interaction of an anticancer beta-carboline alkaloid, harmine with GC and AT specific DNA oligonucleotides. ChemicoBiological Interactions, 260, 256-262.

Shi, B., Cao, R., Fan, W., Guo, L., Ma, Q., Chen, X., Zhang, G., Qiu, L., \& Song, H. (2013). Design, synthesis and in vitro and in vivo antitumor activities of novel bivalent betacarbolines. European Journal of Medicinal Chemistry, 60, $10-22$.

Sodaeizadeh, H., Rafieiolhossaini, M., \& Van Damme, P. (2010). Herbicidal activity of a medicinal plant, Peganum harmala L., and decomposition dynamics of its phytotoxins in the soil. Industrial Crops and Products, 31(2), 385-394.

Song, H., Liu, Y., Liu, Y., Huang, Y., Li, Y., \& Wang, Q. (2014). Design, synthesis, anti-TMV, fungicidal, and insecticidal activity evaluation of 1,2,3,4-tetrahydro-beta-carboline-3-carboxylic acid derivatives based on virus inhibitors of plant sources. Bioorganic \& Medicinal Chemistry Letters, 24(22), 5228-5233.

Waki, H., Park, K. W., Mitro, N., Pei, L., Damoiseaux, R., Wilpitz, D. C., Reue, K., Saez, E., \& Tontonoz, P. (2007). The small molecule harmine is an antidiabetic cell-type-specific regulator of PPAR gamma expression. Cell Metabolism, 5(5), 357-370.

Wu, J., Chen, Q., Cao, R., Yu, F., Wang, Z. \& Peng, W. (2014). Harmine derivatives, intermediates used in their preparations, preparation processes and use thereof. Patent, US 08772311.

Yang, Y., Cheng, X., Liu, W., Chou, G., Wang, Z., \& Wang, C. (2015). Potent AChE and BChE inhibitors isolated from seeds of Peganum harmala Linn by a bioassay-guided fractionation. Journal of Ethnopharmacology, 168, 279-286.

Yoshida, N. (2006). A strategy for controlling pine wilt disease and its application on-site. Journal of the Japanese Forest Society, 88(5), 422-428.

Zhang, L., Teng, L., Gong, C., Liu, W., Cheng, X., Gu, S., Deng, Z., Wang, Z., \& Wang, C. (2013). Simultaneous determination of harmine, harmaline and their metabolites-harmol and harmalol in beagle dog plasma by UPLC-ESI-MS/MS and its application to a pharmacokinetic study. Journal of Pharmaceutical and Biomedical Analysis, 85, 162-168. 
Zhao, T., Ding, K., Zhang, L., Cheng, X., Wang, C. \& Wang, Z. (2013). Acetylcholinesterase and Butyrylcholinesterase inhibitory activities of beta-Carboline and Quinoline alkaloids derivatives from the plants of Genus Peganum. Journal of Chemistry (ID 717232).
Zheng, X., Zhang, Z., Chou, G., Wu, T., Cheng, X., Wang, C., \& Wang, Z. (2009). Acetylcholinesterase inhibitive activityguided isolation of two new alkaloids from seeds of Peganum Nigellastrum Bunge by an in vitro TLCbioautographic assay. Archives of Pharmacal Research, 32(9), 1245-1251. 